\title{
Wilderness protection in Estonia
}

\author{
RICHARD CADDELL
}

\section{Introduction}

Concerns have long been raised that the remaining areas of wilderness in Europe are fragmented, threatened by multiple anthropogenic pressures and in collective retreat. However, as a striking national exception, it has been consistently observed that Estonia has not only retained significant tracts of wilderness-quality land, but concurrently imposes some of the most stringent legal controls over such areas within the EU. ${ }^{1}$ Since its inception Estonia has proved to be a nature conservation actor of understated significance, with an extensive history of environmental innovation, both as an independent state and as a constituent Republic of the Soviet Union. ${ }^{2}$ Within modern-day Estonian territory, the designation of areas subject to minimal human intrusion can be traced back to the thirteenth century. More recently, the coordinated legal protection of natural features by Estonians dates back to 1910, with the designation of the first formalized zapovednik in the Russian Empire, ${ }^{3}$ thereby

* The author is indebted to Uudo Timm and Piret Kiristaja of the Estonian Ministry of the Environment, Kaidi Aher of the Office of the President of the Republic of Estonia, Eleri Lopp-Valdma of Estonian Wildlife Tours (www.estonianwildlifetours.com) and Aivar Ruukel of Sooma.com for additional information on wilderness management and policy in Estonia; the usual caveats apply. This chapter seeks to outline the legal position as of 30 May 2015.

1 See M. Fisher et al., Review of Status and Conservation of Wild Land in Europe (Edinburgh: Scottish Government, 2010), pp. 45-69 and European Commission, Guidelines for the Management of Wilderness and Wild Areas in Natura 2000 (Brussels: European Union, 2012), at 15 .

2 On the historical development of Estonian environmental law see R. Caddell, 'Nature Conservation in Estonia: From Soviet Union to European Union', Journal of Baltic Studies 40 (2009), 307-332.

3 F. Shtilmark, Историография Российких Эаповедников (1895-1995) (Edinburgh: Russian Nature Press, 2003), at 16. The zapovednik system would ultimately govern wilderness areas across the USSR and has remained a highly influential mechanism in many independent post-Soviet states. See also Chapter 19. 
inaugurating what would eventually become an extensive collection of purportedly pristine and undisturbed areas across Eurasia. Numerically, Estonia has established significantly more sites corresponding to the IUCN's specific wilderness Category Ib than any other European jurisdiction and is second only to Sweden in the size of areas so designated. ${ }^{4}$ Indeed, as the national authorities have rather pointedly observed, the '[p]reservation of nature free from human interference is a principle that has been utilized quite often since the earliest days of Estonia's nature conservation system; many countries are now making their first encounter with this idea'. 5

Estonia accordingly represents an intriguing case-study of the protection of wilderness characteristics in a European context. Although the reasons underpinning the success or otherwise of national wilderness policies are essentially peculiar to each jurisdiction, the Estonian experience nonetheless provides insightful lessons for other states, not least in its innovative system of zoning and in regulating the coexistence between protected sites and the burgeoning ecotourism industry. To this end, this chapter first outlines the importance of wilderness in Estonia, detailing the combination of historical factors and the unique physical, social and political geography of the country that has facilitated the retention of considerable areas of wilderness-quality land. There then follows an appraisal of the legal protection of wilderness areas, predominantly through forestry and nature conservation legislation and the management of protected sites. Finally, reflecting the recent views of the European Parliament that wilderness areas are not intended to be hermetically sealed to human interaction, ${ }^{6}$ this chapter examines the regulation of Sooma National Park, which encompasses arguably Estonia's most significant area of wilderness, before drawing some concise conclusions as to the future challenges facing wilderness conservation and management in Estonia.

4 Fisher et al., Review of Status and Conservation of Wild Land in Europe, supra note 1, at 53-55. Nevertheless, wilderness-quality areas may also be protected under IUCN Category Ia, with a number of states establishing considerably more and larger areas under this designation.

5 L. Klein and I. Hermet, Estonian Nature Conservation in 2011 (Tallinn: Estonian Environmental Information Center, 2012), at 24.

6 As the European Parliament has observed, '[w]e have to protect the [sic] nature, but through human use. The territory of Europe is too small to have forbidden areas for its citizens ... Sustainable tourism development is used as a means to give economic value to wilderness and to create support for conservation': European Parliament, Report on Wilderness in Europe; Document (2008/2210(INI)), at 7. 


\section{Wilderness in Estonian geography, culture and society}

The modern Republic of Estonia is a relatively diminutive jurisdiction, comprising a landmass of $45,227 \mathrm{~km}^{2}$. Estonia is a lowland coastal state fringed by over 1500 separate islands, many of which are sparsely habited or otherwise devoid of human activity. Historically, Estonia has been a primarily agrarian society and remains home to an exceptional variety of biodiversity, given its northern latitude, hosting a vast array of flora and fauna. Most significantly from a wilderness standpoint, however, approximately half the Estonian mainland is composed of woodland, while peat bogs occupy a further twenty per cent of national territory, ${ }^{7}$ creating significant tracts of little-populated and rarely-accessed terrain and presenting clear natural barriers to urban spread and accretion.

Specific data on wilderness coverage throughout Estonia are not readily available, nor has a national inventory of wilderness-quality land yet been instituted. Within the context of the Wilderness Quality Index for Europe, however, Estonia is considered to have high areas of wilderness across its eastern frontier with Russia and throughout its western parameters and coastal fringe. ${ }^{8} \mathrm{~A}$ high number of sites within the Estonian network of protected areas correspond to the IUCN's Categories Ia and $\mathrm{Ib}$, denoting areas that are under strict protection from human influence and those containing a significant volume of wilderness, respectively. The national wilderness may therefore be mapped with some degree of clarity with reference to the legal protection accorded to particular locations. Additional areas of wilderness-quality land may also exist beyond this specific legal network. Indeed, numerous areas of the Estonian mainland exhibit at least two of the three wilderness qualities considered within the present project, namely naturalness and an absence of other manifestations of human interaction. Unlike neighbouring territories in Russia and Scandinavia, however, Estonian wilderness areas are comparatively smaller in net length, yet are nonetheless substantial in relative proportion to the national landmass.

Estonia was founded as a sovereign nation in 1918, incorporating the provinces of Estland and northern Livonia, which had been historically controlled by a succession of conquering powers. During the Second World War, Estonia was annexed by the USSR and, to a considerable degree, the current wilderness footprint is attributable - in both a positive

7 T. Leito, K. Kimmel and A. Ader, Estonian Conservation Areas (Tallinn: Ministry of the Environment, 2008), at 7.

8 Fisher et al., Review of Status and Conservation of Wild Land in Europe, supra note 1, at 45. 
and negative sense - to Soviet development policies. As with many former entities of the USSR, the Soviet system bequeathed Estonia a contradictory ecological legacy of ruin and bounty. Indeed, it is an ironic paradox that, although Soviet economic policies were often synonymous with environmental calamity, they simultaneously secured large swathes of pristine wilderness across the various territories of Eurasia. While the fall of communism duly revealed a disturbing litany of environmental degradation throughout the region, the totalitarian shroud of the Iron Curtain also obscured a substantial network of protected sites, alongside numerous additional areas largely untouched by anthropogenic influences. ${ }^{9}$

Three key historical factors may be considered to be especially important in retaining extensive wilderness coverage in Estonia. First, and while hardly a laudable mechanism for the protection of European wilderness, strict controls were established over population movement throughout the Estonian SSR, which ultimately facilitated the maintenance and (re-)establishment of pristine areas. Rural localities in Estonia - which had previously hosted small villages and homesteads were swiftly cleared, thereby perpetuating large tracts of de facto wilderness. Mass deportations were instituted throughout the 1940s to quell the guerrilla resistance of the Metsavennad ('Forest Brothers') to Soviet control, as well as prospective opposition to the impending policy of agricultural collectivization. In 1945, some 136,000 individual farmsteads were operational in Estonia; ${ }^{10}$ by May 1949 sixty-nine per cent of these had been subsumed into the kolkhoz system, ${ }^{11}$ while living conditions within the countryside steadily deteriorated, which further incentivized urban migration. ${ }^{12}$ Meanwhile, from 1946 onwards, large segments of the north and north-western coastline of Estonia were precluded from settlement or were subject to sweeping legal constraints upon access and transit due to their military sensitivity. Consequently, many settlements were virtually abandoned and these areas were subject to minimal

9 Approximately thirty per cent of Central and Eastern European landmass lay under some form of legal protection upon the dissolution of the USSR: P. Pavlínek and J. Pickles, Environmental Transitions: Transformation and Ecological Defence in Central and Eastern Europe (London: Routledge, 2000), at 42.

10 A. Plakans, A Concise History of the Baltic States (Cambridge: Cambridge University Press, 2011), at 367.

11 A. Statiev, The Soviet Counterinsurgency in the Western Borderlands (Cambridge: Cambridge University Press, 2010), at 178.

12 R. Misiunas and R. Taagepera, The Baltic States: Years of Dependence, 1940-1990 (London: Hurst, 1993), at 232. 
development. Accordingly, even some twenty years after the resumption of independence, the majority of Estonia's numerous islands and coastal regions 'are still well preserved and in a relatively untouched state'. ${ }^{13}$

Second, the pristine nature found across the former USSR is often attributable as much - if not more so - to the wholesale inefficiencies in and arbitrary application of centralized economic policies as to deliberate attempts to preserve significant tracts of land. These initiatives often prioritized grandiose industrial projects and failed to exploit natural resources in a rational manner, ensuring that some areas were subject to devastating over-exploitation and inappropriate development, while others remained essentially neglected and underdeveloped, yet also fundamentally unsullied. While Estonia endured the heavy exploitation of its famed reserves of phosphates and oil shale, ${ }^{14}$ such activities were generally concentrated within specific and predictable locations, thereby ensuring that other areas remained essentially untouched. Moreover, the Baltic region was largely spared the more outlandish manifestations of the Soviet determination to 'master' the forces of nature, ensuring that many elements of the natural ecosystem remained fundamentally intact.

Third, these trends were complemented by a strong history of environmental regulation in Estonia that even pre-dates independence. ${ }^{15}$ During the Soviet era, the Estonian authorities adopted the first Republican law on nature protection, thereby placing the procedures for the designation of protected areas on a regularized footing and, as noted below, pioneered a series of conservationist mechanisms with clear benefits for wilderness areas. Indeed, and rather counter-intuitively, Soviet annexation led to little discernible change in proactive environmental management in Estonia, ${ }^{16}$ which suggests that the Estonian authorities exercised a dramatically disproportionate influence over the trajectory of nature conservation policies on both a central and local level.

13 H. Järve et al., 'Comprehensive study of Estonia's coastal zone protection and conservation', Coastline Reports 20 (2012), 63-76, at 64.

14 P.R. Pryde, Environmental Management in the Soviet Union (Cambridge: Cambridge University Press, 1991), at 263.

15 See Caddell, 'Nature Conservation in Estonia: From Soviet Union to European Union', supra note 2, at 310 and R.W. Smurr, Perceptions of Nature, Expressions of Nation: An Environmental History of Estonia (Köln: Lambert Academic Publishing, 2009), especially pp. 27-129.

16 E-L. Tuvi et al., 'Establishment of protected areas in different ecoregions, ecosystems, and diversity hotspots under successive political systems', Biological Conservation 144 (2011), $1726-1732$, at 1728 . 
The continued wilderness presence within Estonia is not the mere product of historical accident; demographic trends in the post-Soviet era have generally militated against population shifts that might adversely affect impact upon the volume of national wilderness coverage. The population of Estonia is small and contracting. The latest census data establishes a national population of 1,294,455 permanent residents, a reduction of five point five per cent from 2000, which is largely attributable to a low birth-rate and significant emigration following EU accession in 2004. ${ }^{17}$ The population is also primarily urbanized and remains located within predictable areas of habitation. Some sixty-seven point nine per cent of the population live in cities, predominantly in the capital Tallinn, which accommodates almost 400,000 residents or approximately one-third of the entire population. Meanwhile, the rural population is generally falling. Of the 4438 officially-registered villages in rural areas, within which wilderness and protected sites are most prevalent, only twelve have a population above 1000 residents (predominantly those located in the Harju region, on the fringes of Tallinn), while 3781 have less than $100 .^{18}$ Road and rail networks follow well-established routes connecting the major population centres; hence the primary areas of habitation are clearly and predictably contained. Allied to this, as noted in Section 3, Estonia has retained a strong regulatory emphasis upon nature conservation and the wilderness areas protected during the Soviet era were reinforced by a series of legal initiatives following the return to independence to ensure the ecological integrity of these sites. Moreover, within these protected areas in Estonia, the general population trend is one of 'rapid decline', especially among the younger generation, notwithstanding a small degree of inverse migration from wealthier citizens seeking to escape the rigours of urban life. ${ }^{19}$

Despite the seemingly favourable conditions for the promotion of wilderness values in Estonia, considerable challenges are nonetheless also apparent. In the first instance, the concept of 'wilderness' as expressed in English has little direct equivalent in many other

17 The most recent census was undertaken in 2011 and concluded in March 2012; the results are published at www.stat.ee (last visited 30 May 2015).

18 Ibid.

19 J. Kliimask et al., 'Nature conservation in remote rural areas: a win-win situation?' in F. Dünkel, M. Herbst and T. Schlengel (eds.), Think Rural! Dynamiken des Wendels in peripheren ländlichen Räumen und ihre Implikatationen für die Daesinsvorsorge (Dordrecht: Springer, 2014), 193-208, at 198. 
languages, ${ }^{20}$ and there is no truly comparable term in Estonian, which may hinder national policies to protect such areas. While Estonian most closely resembles modern Finnish, there is no equivalent to the unique Finnish notion of erämaa outlined in Chapter $14 .^{21}$ Instead, the most common contemporary articulation of the term is metsik loodus, literally translated as 'forest-like nature'. Nevertheless, numerous areas in Estonia that exhibit the three core wilderness qualities nonetheless lie outside the woodland and include the country's many bogs, mires, bays, floodplains, islands and klint, the extensive limestone escarpments unique to the Baltic region. An alternative - if lesser used - term is kõnnumaa, with $k \tilde{n}$ d describing land ( $\mathrm{maa}$ ) that is of modest value in supporting agrarian activities. This, however, raises the false assumption that wilderness protection is accordingly based on default, in the sense that the pristine integrity of an area has endured due to a lack of economic prospects rather than its inherent value as an untouched ecosystem meriting a state of perpetual preservation. As observed below, Estonian nature conservation law provides for the establishment of Wilderness Conservation Zones within protected national areas. This term, however, is used solely in English; the more generic phrase looduslik sihtkaitsevõond is used in Estonian, literally translated as a conservation zone for nature. Ultimately, many modern conservation terms have little historical resonance in the Estonian language, with concepts such as 'landscape' (maastik) having only entered popular usage in the 1990s and bearing a closer linguistic resemblance to the German landschaft, as opposed to the more internationally prevalent English terminology. ${ }^{22}$ Ironically, concepts such as 'wilderness' may be subject to a proactive legal framework in Estonia that is perhaps more capably articulated in other languages than the native tongue.

20 This is starkly exemplified by the Celtic languages of the UK, which struggle to articulate an equivalent concept of wilderness, which is often used interchangeably with a 'desert' or 'uncultivated land' in Scots (fàsach), Irish (fásach), Manx (aaisagh), Cornish (defyth) and Welsh (anialwch). The closest equivalent is arguably the antiquated Welsh word diffeithwch, used predominantly in classical and religious texts, which conveys the sense of an open or 'unmade' place.

21 The popular understanding of luonto in Finnish as denoting 'nature' or 'the natural world' is, however, largely mirrored by the Estonian term loodus.

22 H. Palang et al., 'Social landscape: ten years of planning 'valuable landscapes' in Estonia', Land Use Policy 19 (2011), 19-25, at 23. This is perhaps unsurprising given that the Baltic German community exercised a considerable cultural and linguistic influence over the regime of natural features in the pre-1918 provinces that would ultimately form the territories of Estonia, Latvia and Lithuania. 
Just as the linguistic understanding of the wilderness paradigm in Estonia is markedly distinct to its Anglo-American foundations, so too are national attitudes towards the natural environment in general and uncultivated land subject to minimal human interaction in particular. The Baltic peoples have long identified themselves as having a strong attachment to the natural world, historically worshipping natural features in the Pagan tradition. ${ }^{23}$ This has been particularly pronounced in Estonia, which has retained a strong attachment to particular groves, woodlands and individual natural features, while the traditional nature-orientated festivals to mark the summer solstice, or jaanipäev in Estonian, continue to be celebrated with great fervour across the Baltic States. As with many other civilizations, the natural world has inspired significant works of literature, art and music in Estonia. From the ancient legends of the Kalevipoeg, depicting the playful use of natural features by mythical giants, to the celebrated modern composition Tuul Kõnnumaa Kohal, ${ }^{24}$ the untouched landscape has traditionally provided a notable creative undertone to Estonian culture. Likewise, Estonian literature has long evoked wistful reflection on the preservation of the natural environment and the restoration of virgin land, albeit with additional layers of context and complexity: throughout much of the twentieth century this was primarily asserted as a subversive metaphor for the restoration of Estonian statehood and the dispersal of invasive occupants, rather than a simple paean to the rugged beauty of the Baltic landscape. ${ }^{25}$

Indeed, this complexity is reflected in attempts to ascertain popular attitudes to wilderness protection in Estonia. The available data suggests that unlike the more preservationist stance of Western Europe, a seemingly prevalent view within Estonia is that protected areas 'should not be seen as a system of orders and prohibitions, but the rational and flexible way to maintain the inherited relationships between nature and local people, ${ }^{26}$

23 Plakans, A Concise History of the Baltic States, supra note 10, at 20-25; see also Smurr, Perceptions of Nature, Expressions of Nation: An Environmental History of Estonia, supra note 15, at 2-26. As Smurr observes, even today most ethnic Estonian surnames are directly derived from nature: ibid., p. xviii.

24 This noted choral work by the Estonian Veljo Tormis, a world-renowned classical composer, is most usually translated as Wind over the Barrens, again reflecting the notion of kõnnumaa as a landscape that is less conducive to cultivation and human utility.

25 See further K. Tüür and T. Maran, 'On Estonian nature writing', Estonian Literary Magazine 13 (2001), 4-10.

26 C. Bosangit, J. Raadik and L. Shi, Perception of Wilderness in Finland and Estonia (Wagenigen: WWF, 2004), at 25. While this study should be treated with a degree of caution - canvassing a small pool of national experts and the managers of protected areas, rather than the general public, and eliciting a relatively low response rate - the results are nonetheless illuminating. 
while the national relationship with the 'wilderness' appears to favour human interaction over voluntary avoidance. ${ }^{27}$ More recent investigations of popular interest in the protection of wild animals that thrive in wilderness habitats reveal a notable ambivalence towards wild nature, with at least fifty per cent of those surveyed of the view that it is 'not important'. ${ }^{28}$ Such surveys have, however, been primarily conducted in the context of large carnivores, where there remains a considerable degree of regional antipathy towards wolves in particular, ${ }^{29}$ hence the population may be favourably disposed to certain elements of a resurgent wilderness yet antagonistic towards others. Attitudes towards abandoned and re-wilded land in the Baltic region are, however, generally negative among the local population, ${ }^{30}$ and attempts to celebrate and promote uncultivated land for its own intrinsic merit have been received with hostility and suspicion in rural areas. ${ }^{31}$ Accordingly, as with other jurisdictions, the legal framework of wilderness conservation in Estonia has sought to reconcile the traditional entitlement of human access to the natural environment with the possibility of securing anthropogenic absence and the maintenance of pristine nature sites, to which this chapter now turns.

\section{The legal protection of wilderness}

\subsection{Introduction}

Although Estonia can be generally considered a jurisdiction within which wilderness values have received a strong measure of protection, the notion of 'wilderness' itself is paradoxically absent from national legislation. There is no specific wilderness statute in Estonia, nor indeed is the

27 Ibid., at 67.

28 L. Balčiauskas, M. Kazlausakas and T. Randveer, 'Lynx acceptance in Poland, Lithuania and Estonia', Estonian Journal of Ecology 59 (2010), 52-61, at 58. The most negative attitudes were recorded in South Estonia, where the potential impact of resurgent carnivores would be keenest felt; approximately forty per cent of those polled in Tallinn, however, considered wild nature to be 'very important'.

29 T. Randveer, 'The attitudes of Estonians to large carnivores', Acta Zoologica Lituanica 16 (2006) 119-123.

30 See A. Ruskule et al., 'The perception of abandoned farmland by local people and experts: landscape value and perspectives on future land use', Landscape and Urban Planning 115 (2013), 49-61. The authors note, however, that a higher value is generally placed on the revival of wild land by city-dwellers and those with an advanced educational background.

31 K.Z.S. Schwartz, "Wild horses in a "European wilderness": imagining sustainable development in the post-communist countryside', Cultural Geographies 12 (2005), 292-320 (examining the clash between Western preservationism and Baltic utilitarianism in the context of reintroducing wildlife to abandoned Latvian farmland). 
term either defined or even explicitly referenced within current legal provisions. Nevertheless, a broad mosaic of legal instruments provides a discernible foundation for the protection of wilderness in Estonia. Of these, the most pertinent in safeguarding the three core wilderness qualities considered herein is the Nature Conservation Act 2004, which envisages the maintenance of certain categories of land in an unaltered state and subject to minimal human interaction. In addition, given the dense woodland coverage across many areas of the Estonian mainland, forestry law will also play a significant role in reinforcing national wilderness protection. Other relevant provisions supplementing this broad framework include legislation governing hunting and fishing, agriculture, land regulation, tourism and rights of way, natural heritage and general principles of environmental protection and stewardship.

\subsection{The history of wilderness protection in Estonia}

Despite its truncated history as a sovereign nation, the creation of protected areas subject to minimal human interference has a long heritage in Estonia. The earliest recorded measures for strict nature protection within Estonian territory date back to 1297, where the Danish King Menved prohibited logging on a series of islands fringing the northern coastline so as to assist maritime navigation. Later, under Swedish rule, further restrictions were placed upon the felling of valuable trees and the destruction of forestry resources in 1647 and 1664, culminating in the establishment in 1764 of an extensive protected forest zone, spanning some fifty fathoms in width, across the Baltic coast. ${ }^{32}$ The first formalized nature reserve was inaugurated in Estonia in 1910, with the acquisition of a sizeable tract of land by the Riga Naturalists' Society on the large western island of Saaremaa, inspired by the private lease in 1909 of the Vaika Islands to secure nesting and hatching sites from human intrusion. The Vaika Islands Bird Sanctuary, which remains protected today, was soon joined by a series of nature reserves designated in 1924 by the government of the newly founded Estonia and, although difficulties were encountered in developing a specific national law on nature conservation, which was belatedly concluded in $1935,{ }^{33}$ regular conservation designations continued throughout this era. By 1940, at which point Estonia succumbed to a

${ }^{32}$ K. Sepp et al., 'Prospects for Nature and Landscape Protection in Estonia', Landscape and Urban Planning 46 (1999), 161-167, at 163.

33 Caddell, 'Nature Conservation in Estonia: From Soviet Union to European Union', supra note 2 , at 310 . 
series of wartime annexations, some forty-seven separate nature reserves had been established across the country, a considerable number of which encompassed significant areas of pristine wilderness.

The Vaika Islands reserve is widely credited as being the first zapovednik within the then Russian Empire, a system of nature conservation that was retained by the USSR and subsequently reapplied in Estonia. In principle, zapovednost - the conceptual foundation of the zapovednik system - remains arguably the most explicit legal mechanism for the protection of wilderness values to have been applied in Europe. The term zapovednik, which has little direct equivalent in English, was initially conceived as the complete withdrawal of an area from any form of economic usage, within which the sole permissible anthropogenic activity would be the study of pristine nature. ${ }^{34}$ Soviet-era zapovedniki nonetheless endured a schizophrenic and precarious existence. While the abolition of the private ownership of land in the USSR and the legislative designation of zapovedniki as 'forever withdrawn from economic utilization for scientific-research and cultural-education purposes $^{35}$ provided conditions that were highly conducive to proactive wilderness protection, preservationist intent was frequently subordinated to industrial reality. By 1933 the 'fetish of inviolability' incumbent in zapovednost had been stridently rejected by influential Soviet scientists, ${ }^{36}$ mindful of Stalin's ruthless pursuit of economic progress and the Socialist 'transformation of nature' as a central component of this objective; hence zapovedniki became increasingly zoned to facilitate development projects. Zapovedniki were also viewed with suspicion by the KGB as havens for dissidents, further inhibiting proponents of

34 Shtilmark, Историография Российских Эаповедников (1895-1995), supra note 3, at 1.

35 P.R. Pryde, Conservation in the Soviet Union (Cambridge: Cambridge University Press, 1972), at 212.

36 D.R. Weiner, Models of Nature: Ecology, Conservation and Cultural Revolution in Soviet Russia (Pittsburgh: University of Pittsburgh Press, 1988), at 195. This infamous pronouncement was made at the 1933 annual meeting of the All-Union Conference on Nature Conservation, at a point at which the trend of 'self-criticism' was prevalent and a concerted purge of perceived opponents of Socialist economic progress was firmly underway. While there were many genuine antagonists to the notion of unqualified zapovednost, Shtilmark considers that for others tactical opposition to 'bourgeois' wilderness sites perversely represented the only realistic opportunity to secure their protection - by embracing (and accordingly controlling) the seemingly inevitable process of zoning, important areas of zapovedniki could nonetheless be potentially maintained in a pristine state: Shtilmark, Историография Российских Эаповедников (1895-1995), supra note 3, at 58-83. 
wilderness values. $^{37}$ In the Estonian context, given that the Metsavennad were primarily active in what is now Karula National Park, this is perhaps one instance of Soviet paranoia that was not entirely misplaced. Most significantly, however, responsibility for zapovednik affairs was frequently reassigned between ministries, notably those with a marked pliancy towards industrial production and limited empathy for plaintive supplication as to the innate value of pristine nature. In 1952 Stalin presided over the 'liquidation' of the zapovedniki, from which 128 areas spanning 12.5 million hectares (over zero point five per cent of the entire territory of the USSR) were culled to forty sites with a net volume of approximately 1.5 million hectares. ${ }^{38}$ From 1957 onwards, prompted by Estonian developments, the individual Republics introduced nature conservation laws that would eventually restore zapovednost as a central objective of Soviet protected areas, although in many instances this was 'blatantly disregarded'39 and the zapovedniki never collectively realized their full wilderness potential.

Zapovedniki nonetheless enjoyed a distinctly more favourable existence in the Estonian SSR, in which five were established during the Soviet era. The first four designations were made in 1957, in the wake of the Republic's pioneering Nature Conservation Act, in Matsalu (to protect waterfowl), Nigula (to promote research into bog ecology, also becoming a bird area of international importance in 1979), Viidumäe (to conserve the Saaremaa ecosystem, and which was subsequently expanded in 1979) and Vilsandi (incorporating the original Vaika Islands Bird Sanctuary), while the Endla zapovednik was instituted in 1985 as a wetland reserve. That the Estonian zapovedniki fared considerably better than their eastern counterparts appears attributable both to a proactive system of environmental management and influential conservation personnel, alongside the otherwise poor industrial prospects for this land. ${ }^{40}$

Other legislative possibilities were also deployed to protect the pristine integrity of particular sites, including designation as a zakhaznik. While zakhazniki were not centrally envisaged as wilderness reserves, ' $\mathrm{t}$ ]he Russian republic and some others use[d] this category primarily for game management purposes, whereas the Baltic republics have

37 Weiner, ibid., at 227. ${ }^{38}$ Ibid., at 237.

39 Shtilmark, Историография Российских Эаповедников (1895-1995), supra note 3, at 134 .

40 Tuvi, 'Establishment of Protected Areas in Different Ecoregions, Ecosystems, and Diversity Hotspots under Successive Political Systems', supra note 16, at 1728-1730. 
established them mainly to preserve specific features of the landscape' ${ }^{41}$ In Estonia, zakhazniki supplemented the main zapovedniki by establishing new nature reserves in 1979 at Karula and Otepää and in 1981 at Haanja, Peipsiveere and Piusa. A further zazhaznik established in 1981 for mire protection at Endla was swiftly reconstituted as the Republic's fifth zapovednik, while the Vorsmi zakhaznik (1987) operated in reality as a wilderness reserve, since the island had been abandoned after the Second World War and visitor access was subsequently precluded for security purposes. By the time at which Soviet power disintegrated in 1991, some seven point three four per cent of the Estonian landmass was under formal legal protection, which thereby included a considerable proportion of areas exhibiting distinct wilderness qualities. ${ }^{42}$

The immediate post-Soviet period presented particular challenges to the integrity of the wilderness in the newly re-independent Estonia. The withdrawal of Soviet forces duly facilitated the sudden release of significant areas of de facto wilderness, for which public access had previously been heavily restricted. The ecological effects of the convulsions of regime change have only recently begun to be quantified, for which in Estonia there appears to have been a discernible adverse impact upon species most attenuated to wilderness habitats. ${ }^{43}$ Moreover, the chronic understaffing of the national nature conservation authorities and their limited capacity to enforce protective ordinances facilitated some distinctly rapacious behaviour within these locations. ${ }^{44}$ Ecological considerations would also have to compete for the legislative attention of the nascent government with a host of other pressing matters, while nature conservation itself was a less immediate environmental priority than addressing significant pollution concerns and land remediation requirements. In 1994 a Law on Protected Natural Objects was enacted and, while this facilitated the establishment of four significant nature reserves at Alam-Pedjar (1994), Naissare (1995), Osmussaare (1996) and Silma (1998), this provision is considered to have

41 P.R. Pryde, 'The environmental basis for ethnic unrest in the Baltic republics' in J.M. Stewart (ed.), The Soviet Environment: Problems, Policies and Politics (Cambridge: Cambridge University Press: 1992), 11-23, at 12.

42 S. Sööt, 'Estonia' in in P.R. Pryde (ed.), Environmental Resources and Constraints in the Former Soviet Republics (Boulder: Westview Press, 1995), 95-108, at 105.

43 E.V. Bragina et al., 'Rapid declines of large mammal populations after the collapse of the Soviet Union', Conservation Biology 29 (2015), (in press).

44 M.R. Auer, 'Estonian environmental reforms: a small nation's outsized accomplishments' in M.R. Auer (ed.), Restoring Cursed Earth: Appraising Environmental Policy Reforms in Eastern Europe and Russia (Lanham: Rowman \& Littlefield, 2005), 117-143, at 133-34 (noting wholesale logging and illegal construction in previously secured sites). 
been overly dependent upon a framework approach and the corresponding need to elaborate regular delegated legislation and was thus less able to facilitate proactive nature conservation. ${ }^{45}$ Meanwhile, further complications were raised by the protracted process of land restitution following the confiscation of private property by the Soviet authorities, which could prospectively serve to fracture the connectivity of existing or future protected sites or pockmark particular elements of the remaining Estonian wilderness with development projects.

\subsection{The Nature Conservation Act 2004}

Upon accession to the EU, the 1994 statute was repealed and replaced with the Nature Conservation Act 2004 (NCA), ${ }^{46}$ which seeks to promote a closer legislative alignment with the Habitats Directive. ${ }^{47}$ While the wilderness credentials of the Habitats Directive are somewhat qualified, ${ }^{48}$ the NCA has nonetheless served to facilitate a concerted degree of protection for wilderness sites in Estonia, notably through clear provisions on the zoning of conservation areas to facilitate minimal interference with pristine land. The basic tenet of the NCA is for nature conservation to be realized 'by means of restricting the use of areas important from the aspect of preservation of the natural environment, by regulating steps involving specimens of wild fauna, flora and fungi and specimens of fossils, and by promoting nature education and scientific research'. ${ }^{4}$

The primary mechanism for wilderness conservation within the NCA is Section 4, under which six distinct categories of 'protected natural objects' (kaitstavad loodusobjektid) are recognized, ${ }^{50}$ of which 'protected

${ }^{45} \mathrm{H}$. Veinla, 'Environmental considerations in Estonian land-use legislation', Juridica International 1 (1996), 48-56, at 50. Similar concerns were raised by the European Commission during Estonia's EU accession process: Caddell, 'Nature Conservation in Estonia: From Soviet Union to European Union', supra note 2, at 315-317.

46 On the NCA generally see H. Veinla and K. Relve, Environmental Law in Estonia (Aalpen aan den Rijn: Kluwer, 2012), at 153-167.

47 Council Directive 92/43/EEC of 21 May 1992 on the conservation of natural habitats of wild flora and fauna [1992] OJ L206/7.

48 See further Chapter 8.

49 Section 2(1). The protection of 'animals living freely in the wild' is vested exclusively in the NCA: see the Animal Protection Act 2000, Sections 1(2) and 6(1). Hunting and fishing is generally prohibited within designated conservation zones and is regulated respectively under the specific legislation governing these activities.

50 Namely, protected areas, limited conservation areas, protected species and fossils, species protection sites, individual protected natural objects and natural objects protected at the local government level: Section 4(1). 
areas' (kaitsealad) present the clearest possibilities for the untrammelled protection of pristine nature. Indeed, protected areas are to be 'maintained in a state unaltered by human activity or used subject to special requirements where the natural environment is preserved, protected, restored, researched or introduced'. ${ }^{51}$ Responsibility for the designation of protected natural objects - including protected areas exhibiting wilderness qualities - is vested in the Ministry of the Environment, ${ }^{52}$ although '[e]veryone' may propose additional sites for incorporation into the national network. ${ }^{53}$ Once designated, protected areas are subject to individual protection rules, ${ }^{54}$ through which the distinct ecological character of each site - including any specific wilderness requirements will be managed. In this regard, the protection rules are to establish 'one or several protected zones with equivalent or different degree of strictness of restrictions, ${ }^{55}$ while a specific management plan is also to be established for the site ${ }^{56}$ providing further scope to address particular wilderness considerations.

Three specific categories of 'protected area' are envisaged under the Estonian system, namely national parks (rahvuspargid), nature reserves (looduskaitsealad) and landscape protection areas (maastikukaitsealad). ${ }^{57}$

\section{Protected areas}

National parks are defined in Section 26(1) as 'a protected area prescribed for the preservation, protection, restoration, research and introduction of the natural environment, landscapes, cultural heritage and balanced use of the environment of the protected area'. Five such areas have been established to date: Laahemaa, initially created in 1971 during the Soviet period, to protect the coastal landscapes of Northern Estonia; Karula, established in 1993 from an earlier zakhaznik, to protect the hilly moraine landscapes of Southern Estonia; Soomaa, established in 1993, to protect the mire and floodplain landscape of Estonia intermedia; Vilsandi, designated in 1993 to protect the Western Estonian archipelago

51 Section 4(2) (emphasis added). $\quad{ }^{52}$ Section 9. $\quad{ }^{53}$ Section 8(1). ${ }^{54}$ Section 12(1).

55 Section 12(2). ${ }^{56}$ Section 25.

57 There is some inconsistency in the official English translation of the NCA, with looduskaitsealad described in Section 4(2)(2) as 'nature conservation areas' but as 'nature reserves' in Section 27. The latter construction has been used in this chapter, since Section 27 establishes the definition and functions of looduskaitsealad on a more extensive basis and the term 'nature reserve' is predominantly used in the English translation of official documents pertaining to this category; the original Estonian language version is clear that the areas addressed by Sections 4(2)(2) and 27 are one and the same. 
and Matsalu (2004) in the Väinameri Sea region, both of which had been previously established as zapovedniki in 1957. National parks are therefore intended under the NCA to operate as multi-use sites, wherein wilderness objectives are to be reconciled with recreational uses and cultural heritage considerations.

This approach reflects the historical practices of such sites in Estonia, which, alongside other national parks in the Baltic region, have a multifaceted provenance. Lahemaa is notable as the first national park to have been created within the USSR, then representing a novel designation of protected area beyond the zapovednik system. While it was (and remains) unquestionably significant from an environmental perspective, nature protection was nevertheless far from the sole objective underpinning its creation, for Lahemaa was conceived as a means of preserving indigenous Estonian culture just as much as its native ecosystem. ${ }^{58}$ Mixed motives notwithstanding, as one of Estonia's most pristine and sparsely populated areas, Lahemaa swiftly assumed a significant role in wilderness preservation and a core part of its original mandate was 'to preserve special regions within the park in conditions of pristine natural condition for the observance and research of natural processes' ${ }^{59}$ Indeed, some six to eight per cent of the park was ultimately withdrawn specifically to preserve its wilderness character, while a further two-thirds of the park was available only to the most passive forms of recreation. ${ }^{60}$

This broad practice has endured within the current legislative framework. Three distinct types of zones are envisaged within national parks, namely 'strict nature reserves' (loodusreservaat), 'conservation zones' (sihtkaitsevöönd) and 'limited management zones' (piiranguvöönd). ${ }^{61}$ Of these, strict nature reserves and conservation zones present the clearest mechanisms for the protection of wilderness values within nationally protected areas. From a specific wilderness standpoint, limited management zones are generally unsuited to wilderness conservation since an array of intrusive economic activities may be permitted within these sites, including mineral extraction, landscape modification and extensive access by visitors and most forms of vehicles. ${ }^{62}$

58 R.W. Smurr, 'Lahemaa: the paradox of the USSR's first national park', Nationalities Papers 36 (2008), 399-423, at 411. Similar parks - with broadly similar objectives were soon established in Latvia (Gauja, 1972) and Lithuania (Augštaitija, 1974).

59 Lahemaa Rahvuspargi Põhimäärus; reproduced ibid., at 404.

60 P.R. Pryde, Environmental Management in the Soviet Union, supra note 14, at 162.

61 Section 26(3). ${ }^{62}$ Section 31. 
Strict nature reserves are defined in Section 29(1) as 'a land or water area of a protected area whose natural status is unaffected by direct human activity and where the preservation and development of natural biotic communities is ensured only through natural processes'. More significantly from a wilderness perspective, '[a]ll types of human activity' are prohibited within such areas, ${ }^{63}$ with exceptions granted solely for supervision, rescue work and to organize the protection of the area itself, $^{64}$ or for the monitoring and assessment of the site, ${ }^{65}$ a position largely reflective of the original intentions of zapovednost.

Conservation zones are defined as 'a land or water area of a protected area prescribed for the preservation of natural and semi-biotic communities established or to be developed therein. Mineral resources present within a conservation zone are not deemed to be resources intended for exploitation. ${ }^{\prime 66}$ Within designated conservation zones, general prohibitions are imposed upon economic activities, the use of natural resources, construction work, interference with protected habitats, driving motor vehicles, off-road vehicles or vessels, as well as camping, building fires or organizing public events. ${ }^{67}$ Likewise, the protection rules established for a conservation zone may, with the approval of the responsible authorities, permit a wider degree of human interaction with the site than is contemplated for strict nature reserves. This will include, to a greater or lesser extent and on the proviso that the preservation of the area is not compromised, maintenance work, development of biotic communities, gathering berries, fungi and other forest products, hunting and fishing, the establishment of roads, conservation activities and the gathering of reed and seaweed. ${ }^{68}$ In practice, and although no explicit distinction is made concerning sihtkaitsevöönd within the MCA, two broad categories of conservation zone have been established, namely Wilderness Conservation Zones (WCZs) and Managed Conservation Zones (MCZs). The distinction is drawn depending on whether the area in question is to be maintained in either a natural or semi-natural state: MCZs are generally applied where some form of human intervention is necessary to preserve the natural values of the land, in particular maintaining the wooded meadows (puisniidud) that remain a unique feature

63 Section 29(2). $\quad{ }^{64}$ Section 29(3). $\quad{ }^{65}$ Section 29(4).

66 Section 30(1). This latter position is reinforced in Section 20(1)(1) of the Earth's Crust Act 2004 , which precludes the granting of permits where the proposed activities would damage a protected natural object.

67 Section 30(2). ${ }^{68}$ Section 30(4). 
of the Estonian countryside, while WCZs are considered to be essentially free from anthropogenic activities.

A broadly similar position applies in the other two categories of protected area recognized under the NCA. As with national parks, a nature reserve - which is 'prescribed for the preservation, protection, restoration, research and introduction of the natural environment ${ }^{69}$ may also comprise a series of strict nature reserves, conservation zones and limited management zones. ${ }^{70}$ Landscape protection areas, in contrast, are specifically established to preserve the integrity of the landscape, rather than the natural environment, ${ }^{71}$ with wilderness conservation a lesser priority. Strict nature reserves are not contemplated for these areas, although they may incorporate sihtkaitsevöönd, ${ }^{72}$ which will in practice include a smaller number of designations as WCZs.

\section{Current status of 'wilderness designations'}

Inventories of protected areas are conducted periodically in Estonia, most recently in 2011, which provides an official record of the current status of wilderness designations under the NCA. To date, twenty-nine strict nature reserves have been established, comprising a combined total of 7958 hectares or some 0.002 per cent of Estonian territory, ${ }^{73}$ with such designations having remained static in number and area since the previous inventory in 2007. As of 2011, 316 WCZs had been created, comprising a total area of 189,246 hectares, which represents a numerical increase by two sites but a net reduction of 516 hectares. ${ }^{74}$ Protected wilderness sites are most prevalent within nature reserves: three per cent of the net territory of these zones has been designated as strict nature reserves and forty-three per cent as WCZs. ${ }^{75}$ Across the five national parks, one per cent of the land cumulatively constitutes a strict nature reserve and thirty-three per cent has been established as a network of WCZs. ${ }^{76}$ Additionally, some six per cent of the combined total of land designated as landscape protected areas has been established as a WCZ. ${ }^{77}$

${ }^{69}$ Section $27(1) . \quad{ }^{70}$ Section $27(2)$.

${ }^{71}$ Section $28(1)$. Unlike the other two categories of 'protected area', the protection of the natural environment is absent from the definitional objectives of a landscape protection area.

72 Section 28(2).

73 Klein and Hermet, Estonian Nature Conservation in 2011, supra note 5, at 54.

${ }^{74} \mathrm{Ibid}$., at $55 .{ }^{75} \mathrm{Ibid}$., at $41 .{ }^{76} \mathrm{Ibid}$., at $40 .{ }^{77} \mathrm{Ibid}$., at 42. 
Public access to wilderness sites

Public access to wilderness sites is not precluded, although it is subject to extensive regulation. Reflecting its early heritage as an outpost of a succession of Scandinavian empires, Estonia has retained the Nordic tradition of the 'everyman's right' (igameheõigus), prescribing a customary privilege to freely roam the land between sunrise and sunset. Although there is no general public right of access to strict nature reserves, ${ }^{78}$ the igameheõigus expressly applies, inter alia, to conservation zones, ${ }^{79}$ which would accordingly extend to sites designated as WCZs. The specific parameters of the igameheõigus, which had previously lay scattered across a disparate array of statutes, have recently been collated in the Environmental Code Act 2011 (General Part), for which the relevant provisions formally entered into force on 1 August 2014. The exercise of the igameheõigus is a residual freedom, contingent upon the permission of the owner of the land - whether public or private - which is deemed to have been granted if the owner has not fenced the plot or marked it in a manner that demonstrates the intent to restrict strangers' stay on the plot. ${ }^{80}$ On 3 March 2015, the Act was amended to withdraw this general presumption in the specific case of power-driven or off-road vehicles; ${ }^{81}$ the Estonian legislation therefore provides a clear regulatory position on activities that have raised significant concerns in the wilderness environments of other jurisdictions.

Where applicable, the igameheõigus prescribes a general entitlement to pick berries, mushrooms and nuts and to take any other natural products, unless this is clearly prohibited by the owner. ${ }^{82}$ Permission to camp on land is presumed only for one day, ${ }^{83}$ while fires may be lit solely in areas for which specific authorization has been granted. ${ }^{84}$ Visitor access to protected areas across Estonia has accordingly been clearly demarcated through suitable fencing and signposting. The State Forestry Management Centre has also established an authoritative list of sites suitable for public amenity, while specifying locations that are not to be disturbed and within which the igameheõigus will explicitly

78 Section 29(2). ${ }^{79}$ Section 15(1).

80 Section 32(2). Access to shores and banks is guaranteed under Section 36 of the NCA.

81 Section 32(2); the amendments entered into force on 14 March 2015. Provision for further restrictions on vehicular access to remote areas is established under Section 5(1) of the Roads Act 1999.

82 Section 34. This general position is reinforced by Section 35 of the Forest Act 2006 in relation to woodland areas.

${ }^{83}$ Section 35(3). ${ }^{84}$ Section 36. 
not apply. ${ }^{85}$ Responsibility for the enforcement of these provisions is vested in the Environment Board, which has established a 24-hour hotline for the anonymous reporting of environmental infractions. There has generally proved to be a high level of compliance with the relevant wilderness restrictions, ${ }^{86}$ a position that appears largely attributable to the clear information concerning limitations upon access to particular areas and the concerted provision of amenities and recreational sites for visitors.

\section{Wilderness and forestry protection}

Given that significant areas of pristine nature remain located within the extensive Estonian woodland, the regime of forestry protection is also highly pertinent in promoting wilderness conservation. Land-use changes and the collectivization of agriculture led to a dramatic increase in forest coverage during the Soviet era, ${ }^{87}$ which now accounts for approximately fifty per cent of the national landmass. Forestry resources are regulated under the Forest Act 2006, which prescribes a legal requirement that state-owned forestry shall encompass at least twenty per cent of the total area of the Estonian mainland. ${ }^{88}$

The Forest Act presents particular scope to assist in wilderness conservation through the establishment of a network of Woodland Key Habitats (WKHs), each of which span at least seven hectares. ${ }^{89}$ Economic activities may be restricted or even prohibited entirely within WKHs; ${ }^{90}$ approximately thirty-one per cent of Estonian forestland is currently subject to management restrictions. ${ }^{91}$ Privately-owned forestry may also be co-opted into this network, whereby a mandatory twentyyear lease is concluded for the land in question. ${ }^{92}$ Private owners have nevertheless proved reluctant to participate in voluntary initiatives to withdraw their forestry from economic usage, unsurprisingly so where individual sites may have been regained through protracted land

${ }^{85}$ For full details see www.looduseakoos.ee (last visited 30 May 2015).

${ }^{86}$ Personal communication with Mr Uudo Timm of the Estonian Ministry of the Environment (on file with the author).

${ }^{87}$ Forest coverage increased from 929,000 hectares in 1940 to 2,022,000 hectares in 1993: E. Urbel-Piirsalu and A-K. Bäcklund, 'Exploring the sustainability of Estonian forestry: the socio-economic drivers', Ambio 38 (2009), 101-108, at 101.

${ }^{88}$ Section 5(1). ${ }^{89}$ Article 23(1). ${ }^{90}$ Article 26(6).

91 R. Sirgmets, P. Kaimre and A. Padari, 'Economic impact of enlarging the area of protected forests in Estonia', Forest Policy and Economics 13 (2011) 155-158, at 155.

92 Section 26(4). 
restitution proceedings; hence compulsory leases have been an important tool in maintaining the integrity of the WKH network. ${ }^{93}$

Significantly, from a wilderness standpoint, forest resources are also subject to an overarching development plan to be concluded on a tenyearly basis. ${ }^{94}$ This includes provision for the withdrawal of a certain volume of forestry from economic use and its preservation as a de facto wilderness area. The latest Forest Development Programme, concluded in 2010, mandates the strict protection of at least ten per cent of the total area of Estonian forestry, thereby supplementing current wilderness designations under the NCA for an extended period of time.

\section{Wilderness and heritage law}

Finally, the network of protected wilderness areas established under the NCA may be complemented to some degree by designations for heritage purposes. Given Estonia's pagan heritage, and a post-Soviet revival of the indigenous nature-based religions of Maausk and Taarusk, the natural environment has retained a strong cultural resonance. Numerous sites protected under the NCA also host natural features that are significant examples of cultural heritage. This includes an extensive volume of hiied (sacred groves), within which ancient lore has traditionally mandated an absence of cultivation. ${ }^{95}$ A definitive inventory of sacred natural sites is currently being compiled in Estonia, ${ }^{96}$ for which the Heritage Conservation Act 2002 facilitates the designation of heritage conservation areas to preserve monuments of national significance. ${ }^{9}$

Unlike other jurisdictions, however, cultural heritage legislation is of comparatively modest utility in protecting wilderness values in Estonia: a protected zone is presumed to extend for only fifty metres around the monument, ${ }^{98}$ public access is to be guaranteed ${ }^{99}$ and the designation criteria applies to sites that 'have developed under the joint influence of

${ }^{93}$ P. Põllumäe, H. Korjus and T. Paluots, 'Management motivations of Estonian forest owners', Forest Policy and Economics 42 (2014), 8-14, at 11.

${ }^{94}$ Section 7(2). Approximately one quarter of all WKHs are located on privately-owned land: Klein and Hermet, Estonian Nature Conservation in 2011, supra note 5, at 51.

95 On the pristine nature of hiied see T. Jonuks, 'Holy groves in Estonian religion', Estonian Journal of Archaeology 11 (2007), 3-35, p.17.

96 State Conservation Plan for Sacred Natural Sites 2008-12 (Tallinn: Estonian Ministry of Culture, 2008), Objective 1. Placing such items under formal legal protection remains an on-going process (Objective 2).

97 Section 15. ${ }^{98}$ Section 25(3). 99 Section 27. 
natural phenomena and human activities'. ${ }^{100}$ Moreover, hiied aside (which often vary substantially in size), natural items of cultural significance in Estonia have generally comprised individual features, such as glacial erratic boulders, cross-trees, cup-stones and traditional boundary markers, rather than large sites valued for their wilderness characteristics. Most significantly, perhaps, the relationship between wilderness values and cultural heritage in Estonia remains complex and divisive. Attempts to reintroduce primordial nature within protected rural areas that are also representative of longstanding agrarian traditions have been staunchly resisted by supporters of heritage values. Indeed, this dichotomy has been most starkly illustrated in the context of Lahemaa National Park, where proponents of wilderness restoration have faced concerted opposition from those seeking to preserve its distinct traditions of cultivation. $^{101}$

\section{Future challenges}

The current legislation provides an effective template for the preservation of significant areas of land in Estonia exhibiting a high state of naturalness and a general absence of anthropogenic infrastructure. Indeed, it can be seen that this framework has facilitated the withdrawal of a significant volume of territory across Estonia as pristine wilderness, for which a high degree of public cooperation has been forthcoming. However, the perceived conflict with cultural values and the Baltic heritage of shaping the landscape is not the only challenge to coordinated wilderness conservation in Estonia. It would appear that the current range of wilderness designations is approaching its full capacity within a relatively small territory and the scope to withdraw further expanses of land as pristine sites may be decidedly limited. Indeed, the more recent trend is for conservation designations to be established as managed zones, which remain under protection but with a clear toleration for socio-economic

100 Section 4(1). Likewise, Estonia has also nominated a series of puisniidud for inclusion upon the Tentative List of the World Heritage Convention, although this specifically celebrates the fact that human cultivation prevents these distinct natural areas from becoming overgrown and subsumed into a wilderness environment.

101 M. Kõivupuu, A. Printsmann and H. Palang, 'From inventory to identity? Constructing the Lahemaa National Park's (Estonia) regional cultural heritage' in T. Bloemers, H. Kars, A. van der Valk and M. Wijnen (eds.), The Cultural Landscape and Heritage Paradox (Amsterdam: Amsterdam University Press, 2010), 115-131, at 124-125. Similar conflicts have occurred in Latvia: K.Z.S. Schwartz, "Masters in our native place”: The politics of Latvian national parks on the road from communism to "Europe", Political Geography 25 (2006), 42-71, at 55. 
activities. Moreover, there appears to be discernible pressure to renew the protection rules for existing conservation areas in favour of a softer management regime within particular sites. ${ }^{102}$ Ultimately, support for the economic transformation of land previously precluded from use under the Soviet regime has proved to be rather more vociferous across the Baltic States than advocacy for its continued enclosure. ${ }^{103}$

Likewise, land ownership also presents further complications. While a considerable number of land restitution claims have been settled and the overwhelming majority of wilderness designations concern state-owned land, ${ }^{104}$ questions over title to parcels of territory in remote areas remain outstanding. Moreover, although the European Commission has considered that clear lines of communication with those affected by the withdrawal of land - whether as landowners or traditional land-users remains an essential component of effective national wilderness policies, ${ }^{105}$ there has been a decidedly chequered record of consultation within the Baltic States concerning conservation designations. ${ }^{106}$ Tensions also remain concerning the balancing of nature protection considerations with economic development, especially in remote areas: in this respect, industrial activities in the Selisoo bog region, a candidate site for the Natura 2000 network, will constitute a significant test case for Estonia's application of the Habitats Directive. ${ }^{107}$ Ultimately, it appears that for wilderness conservation to further thrive in Estonia, clear accommodations must be made between ecological, developmental and cultural

102 Personal communication with Uudo Timm, supra note 86.

103 Ü. Mander and R. Kuuba, 'Changing landscapes in Northern Europe based on examples from Baltic countries' in R.H.G. Jongman (ed.), The New Dimensions of the European Landscape (Dordrecht: Springer, 2004) 123-134, at 124.

104 Currently, ninety-nine point eight per cent of all strict nature reserves are located on state-owned land, while ninety-two per cent of WCZs are state-owned, six per cent lie on unregistered land and two per cent occur upon private property: Klein and Hermet, Estonian Nature Conservation in 2011, supra note 5, at 62.

105 European Commission, Guidelines for the Management of Wilderness and Wild Areas in Natura 2000, supra note 1, at 65-66.

106 This has been particularly acute in Estonia: see M. Suškevičs and M. Külvik, 'The role of information, knowledge, and acceptance during landowner participation in the Natura 2000 designations: The cases of Otepää and Kõnumaa, Estonia' in M. Jones and M. Stenseke (eds.), The European Landscape Convention: Challenges of Participation (Dordrecht: Springer, 2011), 275-294. Similar problems have been experienced in Latvia: see I. Pavasars, 'Environmentalism in Latvia: Two realities', Journal of Baltic Studies 45 (2014), 39-54, at 42-51.

107 On these developments see A. Marandi, H. Veinla and E. Karro, 'Legal aspects related to the effect of underground mining close to the site entered into the list of potential Natura 2000 network areas', Environmental Science and Policy 38 (2014), 217-224. 
values. To this end, ecotourism constitutes an intriguing prospect for reconciling these competing interests, which this chapter now moves to consider.

\section{Wilderness management and the regulation of ecotourism}

An issue of emerging significance for the protection of wilderness areas is the prospect of increasing ecotourism within the Estonian hinterland. The exploration of the natural environment has long been a favoured recreational pursuit in Estonia and an organized nature tourism industry can be traced back to the $1930 \mathrm{~s},{ }^{108}$ although this largely fell into abeyance during the Soviet period, due to transit restrictions throughout the Estonian SSR and the promotion of tourism to sites of supposed Socialist importance. ${ }^{109}$ Following the resumption of independence, the national authorities and individual entrepreneurs were swift to appreciate the significant tourism potential of Estonia's pristine landscape, ${ }^{110}$ even if the facilities and infrastructure necessary for viable rural tourism were distinctly lacking in the immediate post-Soviet period. ${ }^{111}$ Although still relatively small, the ecotourism sector has expanded considerably over the past decade, with a consistent market for wilderness experiences having emerged in recent years. Of particular significance in this context is the regulatory regime established in respect of Soomaa National Park, although a degree of well-managed wilderness tourism also occurs in a considerable number of sites throughout Estonia.

The Soomaa region, located in the south-eastern corner of the country, constitutes the most significant area of wilderness in Estonia. Soomaa ('land of swamps') comprises a sparsely populated network of large bogs, woodland and floodplain and is notable for its pristine mire ecosystem and the so-called fifth season, during which the area is subject to extensive flooding. Elements of Soomaa have been protected since 1981, with

108 H. Tooman and A. Ruukel, 'Sustainable development of a remote tourist destination: The case of Soomaa National Park, Estonia' in P. Sloane, C. Simons-Kaufman and W. Legrand (eds.), Sustainable Hospitality and Tourism as Motors of Development: Case Studies from Developing Regions in the World (Abingdon: Routledge, 2012), 276-295, at 278.

109 See A.E. Gorusch, 'All This is Your World': Soviet Tourism at Home and Abroad after Stalin (Oxford: Oxford University Press, 2011), pp. 49-78.

110 R. Jaakson, 'Tourism in transition in post-Soviet Estonia', Annals of Tourism Research 23 (1996), 617-634, at 628.

111 T. Unwin, 'Tourist development in Estonia: Images, sustainability and integrated rural development', Tourism Management (1996), 265-276, at 269-272. 
conservation designations made for its four main bogs of Kuresoo, Valgeaba, Kikipera and Öördi; the area was subsequently reconstituted in 1993 as Estonia's youngest and second-largest national park. Soomaa has been designated a Ramsar Wetland of International Importance since 1997 and, most significantly from the perspective of wilderness ecotourism, received PAN Park status in 2009, the only such designation in Estonia and one of two within the Baltic states. ${ }^{112}$

Soomaa is subject to multiple conservation designations under the NCA. A small area of Kikipera has been established as a strict nature reserve, with extensive WCZs instituted across its main bog areas, alongside a small proportion of MCZs and limited management zones to facilitate visitor access and human habitation. ${ }^{113}$ Ecotourism activities are therefore largely regulated under the NCA in relation to these protected sites. In practice, however, tourism management has been facilitated through the further zoning of the area of the national park under the Management Plan developed for the site, establishing four clear zones of activity. Minimal visitation is to occur within the zones subject to strict protection rules and those under WCZ status, while tourism is instead largely confined to the 'immediate surroundings' of the national park and the 'further surroundings' provide scope for more intrusive activities, such as off-road driving. ${ }^{114}$ Following the practices generally adopted for protected areas, the authorities have clearly designated locations within which tourist access is prohibited, while maintaining a network of paths and walkways to ensure that visitors remain within the minimal infrastructure established within the confines of the site. This has helped to avoid some of the initial difficulties posed to wildlife habitats by poorly planned tourism facilities that had been previously encountered in other protected areas. ${ }^{115}$

In essence, the relatively small number of ecotourism operators has served to ensure that the anthropogenic footprint implanted by the

112 Cepkeliai-Dzukija National Park, located on the Lithuania-Belarus frontier, was incorporated into the PAN network in 2011. Soomaa National Park also received the EU's EDEN award in 2009 for promoting sustainable ecotourism.

113 A clear map of the regulatory area is reproduced in Fisher et al., Review of Status and Conservation of Wild Land in Europe, supra note 1, at 105.

114 Sustainable Tourism Strategy of the Soomaa NP Region 2009-2013 (Soomaa: Soomaa National Park, 2009), at 20-24.

115 Some of the walkways placed for visitor access within Nigula National Park were subsequently considered to have affected the distribution pattern and population of birds: K. Kimmel et al., 'The status, conservation and sustainable use of Estonian wetlands', Wetlands Ecology and Management 18 (2010), 375-395, at 389. 
industry in the Estonian wilderness has been as innocuous as possible. Such operators are generally well apprised of their responsibilities towards the wilderness environment ${ }^{116}$ and, ultimately, a sense of economic Darwinism prevails. Ecotourism entrepreneurs have swiftly appreciated that a high level of compliance with environmental provisions imbues their operations with a high degree of reputability that is a significant marketing benefit for the lucrative foreign market. ${ }^{117}$ Nor has the cultural significance of wilderness tourism been lost on domestic constituents, with the protective environment of Soomaa having facilitated a re-engagement with regional traditions, notably a revival of the crafting of haabja (traditional canoes), which had lapsed almost to extinction during the Soviet period. ${ }^{118}$ Moreover, many such operators are also trained ecologists - a number of whom are noted experts in their fields - and have generally taken a long-term view of the wilderness environment and their role in its preservation. ${ }^{119}$ A significant unifying ethos between nature tourism operators is accordingly to foster a strong understanding of, and concern for, wilderness values among visitors, which is intended in turn to promote the ongoing cause of wilderness protection in Estonia. ${ }^{120}$

\section{Concluding remarks}

As one of the few remaining territories of Europe within which extensive wilderness coverage has endured, Estonia represents an illuminating case-study of the legal protection of wilderness values. A unique combination of circumstances has facilitated the retention of significant tracts of wilderness-quality land in Estonia. The primary drivers of this have

116 Tooman and Ruukel, 'Sustainable Development of a Remote Tourist Destination: The Case of Soomaa National Park, Estonia', supra note 101, at 292.

117 See M. Reimann, M-L. Lamp and H. Palang, 'Tourism impacts and local communities in Estonian national parks', Scandinavian Journal of Hospitality and Tourism 11 (2011), 87-99.

118 Tooman and Ruukel, 'Sustainable Development of a Remote Tourist Destination: The Case of Soomaa National Park, Estonia', supra note 101, at 291.

119 As one leading operator notes in the context of the popular flying squirrel, tours should not be given in relation to species that are not currently able to support such activities and prospective clients are instead referred to reputable operators in Finland, with a view towards establishing a more ecologically viable experience in Estonia within 5-10 years: personal communication with Mr Eleri Lopp-Valdma of Estonian Wildlife Tours (on file with the author).

120 Personal communication with Mr Aivar Ruukel of Soomaa.com (on file with the author); similar sentiments were expressed by Mr Lopp-Valdma, ibid. 
been a small demographic with predictable areas of population density, the limited industrial utility of a number of remote locations and the involuntary withdrawal and rewilding of substantial volumes of land, imposed at a time at which many European countries were heavily exploiting their remaining wilderness resources. Since re-independence, Estonia has continued its longstanding traditions of protecting large tracts of territory subject to minimal human intrusion. While the notion of wilderness is not formally articulated within current Estonian legislation, a clear legal platform has nonetheless been established for the preservation of pristine nature. This has been facilitated primarily through nature conservation law, which prescribes a clear basis for the withdrawal of extensive areas from anthropogenic use. These provisions have been instituted effectively in Estonia and a discernible network of protected wilderness areas has emerged across the course of the past twenty years. This regime has been buttressed by forestry regulations, which have secured the further withdrawal of land from economic use and established a legal guarantee that a substantial volume of the national mainland is to remain carpeted by pristine endemic woodland for the long-term future. Moreover, the proactive management of visitor access to natural sites has ensured a high level of compliance with these restrictions, in tandem with the development of a nascent but responsiblyoperated ecotourism industry.

Notwithstanding the significant wilderness designations made to date in Estonia, pressures upon the current volume of wilderness coverage are nonetheless apparent. Given the large amount of land already withdrawn from economic use across a diminutive territory, it appears unlikely that extensive further designations will be forthcoming in the immediate future. Indeed, there is some movement to downgrade elements of existing WCZs to facilitate a greater degree of economic activity across the fringes of the national wilderness, alongside the application of a lighter regulatory touch concerning the management regime for such areas. Wilderness ideals also cohabit uneasily with cultural heritage considerations within particular sites, where the abandonment and rewilding of land is largely antithetical to longstanding agrarian traditions. The long-term future of wilderness management in Estonia accordingly depends upon the ability of the national authorities to balance these various interests. In the meantime, however, Estonia remains a jurisdiction in which wilderness enthusiasts can not only observe significant expanses of pristine nature, but also the clear and pragmatic application of legal principles to facilitate its ongoing protection. 